Published in final edited form as:

Inflamm Bowel Dis. 2012 January ; 18(1): 187-193. doi:10.1002/ibd.21691.

\title{
microRNAs in Inflammatory Bowel Disease
}

Joel R. Pekow and John H Kwon

Section of Gastroenterology, Hepatology, and Nutrition, University of Chicago, Chicago, IL

\section{Abstract}

MicroRNAs (miRNAs) are small, noncoding RNAs that regulate gene and protein expression. miRNAs are critical to a normal immune response and have altered expression in multiple immune-mediated disorders. This emerging role of miRNAs in the pathogenesis of multiple disease states has led to investigations into miRNA expression profiles in inflammatory bowel disease (IBD). The discovery of miRNAs in IBD is likely to contribute to our understanding of IBD pathogenesis and lead to clinical advances in IBD. This review focuses on miRNA expression in inflammation, autoimmune disorders, and inflammation-associated cancer, as well as their function in the biology and management of IBD.

Inflammatory bowel disease (IBD) is believed to develop via a complex interaction between genetics, immune response, and environmental factors. This interaction is reflected in broad gene expression changes which occur in both Crohn's disease (CD) and ulcerative colitis (UC). ${ }^{1-5}$ As there is a heterogeneous phenotypic spectrum in IBD, known pathophysiologic mechanisms in CD and UC share common pathways while differing in others. ${ }^{6-8}$ These differences and similarities are consistent with findings from gene expression studies which suggest that gene expression profiles can distinguish CD from UC as well as predict a response to therapy. 9,10

Gene expression is regulated in part by a recently described class of noncoding RNAs, termed microRNAs (miRNAs). As such, miRNAs have increasingly been used to distinguish disease phenotypes, including IBD. Furthermore, there have recently been investigations in understanding disease mechanisms through miRNA regulation of protein expression. These studies may lead to new insights into IBD pathogenesis as well as biomarkers for disease activity and therapeutic response. This review focuses on miRNA expression in autoimmune diseases, inflammation, and inflammation-associated cancer, as well as their potential role in the pathophysiology and management of IBD. Table 1 summarizes the miRNAs expressed in IBD and IBD-associated dysplasia.

\section{MIRNAs}

miRNAs are a recently discovered class of short (18-24 nucleotide), noncoding RNAs that regulate gene expression by binding to the $3^{\prime}$ untranslated region of messenger RNA

(mRNA) and cause either translational inhibition or cleavage of the mRNA complex. ${ }^{11}$ Each

Corresponding Author: John H. Kwon, Section of Gastroenterology, University of Chicago, 900 E. 57th St., KCBD 9118, Mailbox 9 , Chicago, IL 60637, jkwon@medicine.bsd.uchicago.edu. 
miRNA has a complementary binding site on numerous mRNA, and each gene can be regulated by many miRNAs. ${ }^{12,13}$ In fact, it is estimated that over $60 \%$ of mRNA have complementary binding sites for miRNA. ${ }^{14}$ Based on physiologic and developmental cues from the local environment, miRNAs regulate the expression of signaling molecules and play important roles in signal transduction, cell differentiation, proliferation, and apoptosis. ${ }^{15}$ As such, miRNAs are vital in normal stem cell proliferation, epithelial cell differentiation, and deregulated in carcinogenesis, where they can act as oncogenes or tumor suppressors. ${ }^{16,17}$ This oncogenic role has been verified experimentally in an animal model where forced expression of polycistronic miR17-92 cluster accelerated tumor development. ${ }^{18}$ In addition to dysregulated expression in malignancies, recent advancements in the detection and functional analysis of miRNAs have revealed distinct expression patterns in various disease states.

The first miRNA was discovered in experiments by Lee et al ${ }^{19}$ in 1993 . They described a noncoding locus, lin-4, in Caenorhabditis elegans which produced a pair of short RNA segments that resulted in antisense RNA-RNA repression of LIN-14, a protein required for larval development. miRNAs have since been identified in plants, viruses, and animals. Many of these miRNAs display cross-species conservation, emphasizing the importance of their biological role. As of September 2010, 1048 human microRNAs have been discovered (Sanger Database). ${ }^{20}$

miRNAs are transcribed by RNA polymerase II into a hairpin structure composed of a stem and a loop, termed pri-miRNA. ${ }^{11}$ The pri-miRNA complex is cleaved in the nucleus by the RNase III endonuclease, Drosha, into an [almost equal to]70 nucleotide miRNA precursor (pre-miRNA). ${ }^{21}$ Following transport from the nucleus to the cytoplasm, the pre-miRNA is cleaved by the enzyme, dicer, into a double-stranded miRNA complex. ${ }^{21-23}$ In its functional state, the mature miRNA is defined on one end by the Drosha cut and on the other by Dicer processing. One strand of the miRNA is loaded into the RNA induced silencing complex (RISC), which facilitates binding to a complementary mRNA. ${ }^{24}$ miRNA-mRNA binding can result in either translational inhibition or degradation of the mRNA complex. ${ }^{25}$ It is through this mechanism that miRNAs fine-tune protein expression of a cell and are involved in disease pathogenesis.

\section{MIRNAs AND INFLAMMATION}

miRNAs play an important role in the development of cells of the innate and adaptive immune system, as well as in regulating an immune response. ${ }^{26}$ The innate immune response, mediated by myeloid cells, provides the initial defense against pathogens. Macrophages and dendritic cells recognize pathogens via pattern recognition receptors, such as Toll-like receptors (TLR), which leads to downstream activation of signal transduction pathways and results in regulation of inflammatory cytokines. ${ }^{27,} 28$

The importance of miRNAs in the TLR signaling cascade is illustrated by miR-146a, whose expression is induced by exposure to lipopolysaccharide (LPS), peptidoglycan, and flagellin through TLR ligands. ${ }^{28,29}$ In turn, miR-146a reduces expression of TNF-receptor-associated factor (TRAF)-6 and IL-1 receptor associated kinase (IRAK)-1, two target genes of the TLR 
signaling cascade. ${ }^{29}$ Therefore, miR-146a functions in a negative feedback mechanism to prevent excess inflammation. Similarly, miR-9 is induced by TLR4 activated nuclear factor kappa B (NF-[kappa]B) in polymorphonuclear cells and monocytes, and miR-9 is involved in inhibitory feedback at the level of NFKB1, a gene that contributes to NF-[kappa]B protein expression. $^{30}$

In addition to miR-146a and miR-9, miR-155 plays in integral role in the immune response. Of the 100 proteins that are direct targets of miR-155 in HeLa cells, ${ }^{28}$ are involved in innate immunity. ${ }^{31-33}$ Polyriboinosinic:polyribocytidylic acid [poly (I:C)] and interferon beta (IFN[beta]) induce miR-155 expression in murine macrophages. ${ }^{34}$ In addition to stimulation through poly (I:C), miR-155 is induced by several TLR ligands through MyD88- or TRIFdependent signaling pathways and the interferons through tumor necrosis factor alpha (TNF[alpha]) autocrine signaling. miR-155, when induced, is involved in antigen presentation as well as activation of the TNF[alpha] pathway. ${ }^{34}$ As with miR-146a, activation of miR-155 likely results in a negative feedback mechanism by targeting the transcripts of several proteins involved in LPS signaling. ${ }^{35}$ Furthermore, the TLR/ interleukin-1 pathway is a target or miR- $155 .{ }^{36}$ An additional role of miR-155 in the innate immune response is through regulation of suppressor of cytokine signaling-1 (SOCS-1) which controls dendritic cell antigen-presenting capacity. ${ }^{35,}$, 37, 38 As such, loss of miR-155 in dendritic cells results in an inability to activate T cells, confirming the importance of miR-155 in TLR-induced antigen presentation.

In addition to the role miRNAs play in the innate immune response, miRNAs are important in B- and T-cell function. A deficiency of dicer in T-regulatory cells results in loss of suppression activity in vivo, and mice with this mutation develop a fatal autoimmune response. ${ }^{39}$ Additionally, several miRNAs, including miR-155, miR-181a, miR-150, and the miR-17-92 cluster are also involved in Band T-cell regulation. ${ }^{40}$ miR-155 is upregulated in B-cell malignancies, and deletion of miR-155 leads to impaired B-cell memory formation and decreased germinal center response. ${ }^{41,42} \mathrm{miR}-181 \mathrm{a}$ has been shown to have a role in Band T-cell differentiation, and T-cell receptor sensitivity can be modulated by changing expression of miR-181a. ${ }^{40}$ miR-150 is expressed in mature B cells and T cells. Forced overexpression of this miRNA prevents B-cell development by blocking the pro-B to pre-B cell transition. ${ }^{43}$

\section{MIRNAs AND AUTOIMMUNE DISEASE}

The evidence that miRNAs are involved in both the innate and adaptive immune response has prompted several investigations into miRNAs in autoimmune-related disorders, including rheumatoid arthritis (RA), systemic lupus erythematosus (SLE), and psoriasis. ${ }^{44}$ In RA, several authors have demonstrated that miRNA expression is altered in the synovium. miR-146a, miR-155, and miR-203 are expressed at high levels in the synovial tissues of patients with RA. ${ }^{45-47}$ Expression of miR-146a is induced by stimulation of proinflammatory cytokines, IL-1[beta] and TNF[alpha], in RA synovial fibroblasts (RASF). ${ }^{45}$ Cells positive for miR-146a include CD68+ macrophages, several CD3+ T-cell subsets, and CD79a+ B cells. ${ }^{45}$ In RASF, TNF[alpha], IL-1[beta], lipopolysaccharide, poly(I-C), and bacterial lipoprotein can induce miR-155 expression, a finding also seen in 
activated macrophages. ${ }^{34,46}$ Furthermore, forced expression of miR-155 expression results in decreased expression of the matrix metalloproteinases (MMP) 1 and 3, proteins believed to be involved in remodeling of the extracellular matrix. ${ }^{46}$ miR-203, which is also increased in synovial fibroblasts from RA patients compared to those with osteoarthritis, results in increased expression of MMP1 and IL- $6 .{ }^{47}$

miRNA expression is also altered in the peripheral blood in patients with RA. In a study examining miRNAs in the peripheral blood mononuclear cells of patients with RA, miR-146a, miR-155, miR-132, and miR-16 were increased. ${ }^{48}$ Furthermore, miR-146a and miR-16 levels were higher in patients with active disease compared to those without clinical activity, demonstrating their potential role as biomarkers of disease activity. ${ }^{48}$

There have been several investigations that have identified differential expression of miRNAs in SLE. The first study to examine miRNAs in SLE compared peripheral blood mononuclear cells in 23 SLE patients, 10 patients with idiopathic thrombocytopenic purpura (ITP), and 10 healthy controls. ${ }^{49}$ In this analysis, 16 miRNAs had altered expression in SLE compared to normal controls. Of these, 13 miRNAs were also altered in ITP. ${ }^{49} \mathrm{~A}$ second study examined 52 subjects with SLE and 29 normal controls. In this report, miR-146a was significantly reduced in peripheral leukocytes in patients with SLE, and levels were inversely correlated with disease activity as well as activation of the type I interferon pathway. ${ }^{50}$ A more recent analysis in 213 patients with SLE and 209 healthy controls found no association with genetic polymorphisms in miR-146a with SLE. ${ }^{51}$ miRNA expression in lupus nephritis was also examined in a separate study. In this analysis, five miRNA (miR-371-5P, miR-423-5P, miR-638, miR-1224-3P, and miR-663) were differentially express across racial groups compared to normal controls. ${ }^{52}$

miRNAs are also likely involved in the pathogenesis of psoriasis, a disease that may occur in association with IBD. In a study comparing psoriasis to normal controls, miR-203, miR-21, and miR-146a were significantly higher, while miR-123b was decreased in psoriatic skin compared to patients with atopic dermatitis and healthy controls. ${ }^{53}$ miR-203 has its highest expression in skin compared to other organs and is localized to keratinocytes. ${ }^{53}$ Furthermore, one potential target of miR-203, SOCS-3, is upregulated in psoriatic lesions. Suppression of SOCS-3 activity leads to activation of STAT3, which when activated in keratinocytes in transgenic mice leads to the development of psoriasis. ${ }^{53,} 54$

\section{TISSUE MIRNAs AND IBD}

As seen in RA, SLE, and psoriasis, there is increasing data that patients with UC and CD have altered miRNA profiles in involved tissue compared to controls. The first study examining miRNA expression in IBD compared sigmoid colon biopsies from patients with active $\mathrm{UC}$, inactive $\mathrm{UC}$, chronic active $\mathrm{CD}$, irritable bowel syndrome, and microscopic colitis with healthy control subjects. ${ }^{55}$ Eight miRNAs (miR-16, miR-21, miR-23a, miR-24, miR-29a, miR-126, miR-195, and Let-7f) were significantly increased in active UC tissues and three miRNAs (miR-192, miR-375, and miR-422b) were significantly decreased in the UC tissues compared to healthy controls. ${ }^{55}$ miR-192 and miR-21 were the most highly expressed of the active UC-associated miRNAs in human colon tissues. In this patient 
cohort, a CXC chemokine, macrophage inflammatory peptide-2[alpha] (MIP-2[alpha]), was also decreased in active UC. MIP-2[alpha] has a complementary binding site for miR-192 and colocalizes to the epithelium. ${ }^{55}$ Furthermore, TNF[alpha]-induced expression of MIP-2[alpha] was inhibited by a miR-192 mimic in HT29 cells in this study. ${ }^{55} \mathrm{~A}$ second study confirmed that miR-21 was elevated in inflamed tissue from $12 \mathrm{UC}$ patients compared to 12 healthy controls. ${ }^{56}$ This examination also identified miR-155 as upregulated in inflamed tissue ${ }^{56} \mathrm{~A}$ third analysis of miRNAs in UC tissue examined eight UC patients and 10 healthy controls. ${ }^{57}$ Biopsies were obtained from inflamed and noninflamed areas of UC patients. In this study, five miRNAs (miR-29a, miR-29b, miR-126*, miR-127-3p, miR324-3p) were commonly upregulated and four miRNAs (miR-188-5p, miR-25, miR-320a, miR-346) were downregulated in both quiescent as well as active UC compared to healthy controls. One additional miRNA (miR-196a) was significantly dysregulated between quiescent disease and healthy controls, and four miRNAs (miR-7, miR-31, miR-135b, miR-223) were significantly dysregulated between active UC and healthy controls. 57

Two small reports have examined tissue miRNAs in CD. One study examined 13 controls, five patients with sigmoid CD, and six patients with ileal CD. ${ }^{58}$ Three miRNAs (miR-23b, miR-106a, and miR-191) were increased and two miRNAs were decreased (miR-19b, miR-629) by microarray and confirmed by real-time polymerase chain reaction (PCR) in Crohn's colitis compared to healthy controls. In Crohn's ileitis, four miRNAs were found to be elevated by real-time PCR (miR-16, miR-21, miR-223, and miR-594). ${ }^{58}$ A second study examined eight patients with $\mathrm{CD}$, eight patients with $\mathrm{UC}$, and 10 healthy controls. ${ }^{57}$ Biopsies were obtained from inflamed and noninflamed areas of the colon. Eighteen microRNAs were significantly dysregulated in both active and inactive Crohn's colitis. Four additional miRNAs (miR-9, miR-30a, miR-30c, miR-223) were significantly different only in quiescent Crohn's colitis compared to healthy controls, and five miRNAs (miR-9, miR-126, miR-130a, miR-181c, miR-375) were significantly different between inflamed Crohn's colitis and healthy controls. ${ }^{57}$ Interestingly, there was only one common miRNA (miR-106a) described to be dysregulated in Crohn's colitis across the two studies, which may reflect the heterogeneous phenotypic presentation of $\mathrm{CD} .{ }^{57,58}$

Studies examining miRNA expression differences at the tissue level between UC and CD are limited, although the previously mentioned analysis by Fasseu et al ${ }^{57}$ did investigate this comparison in patients with quiescent colitis. In that study, eight miRNAs were commonly expressed in noninflamed CD and UC (mir-26a, miR-29a, miR-29b, miR-30c, miR-126*, miR-127-3p, miR-196a, miR-324-3p). In addition, an in silico clustering analysis identified five miRNAs (mir-26a, miR-29b, miR-126*, miR-127-3p, miR-324-3p) that share coordinated dysregulation of expression both in quiescent and inflamed colonic mucosa of IBD patients, and six miRNAs (miR-150, miR-196b, miR-199a-3p, miR-199b-5p, miR-223, miR-320a) displayed significantly distinct alteration of expression between noninflamed UC and CD colon tissue. This study also analyzed subchromosomal locations where two or more miRNAs colocalized. Several microRNAs mapped within known IBD susceptibility loci, although one chromosomal miRNA cluster (chromosome 14q32.31) identified had not been not previously described. 


\section{miRNAs IN SERUM IN IBD}

One previous study examined peripheral blood miRNAs in IBD. The study examined 13 controls, 14 patients with active $C D$, five patients with inactive $C D, 13$ patients with active UC, and 10 patients with inactive UC. Five miRNAs (miR-199p-5a, miR-362-3p, miR-340*, miR-532-3p, miRplus-E1271) were significantly increased and two miRNAs (miR-149*, miRplusF1065) were significantly decreased in the serum of patients with active $\mathrm{CD}$ compared to healthy controls. Both patients with active or inactive $\mathrm{CD}$ had increased expression of miR-340* and decreased expression of miR-149*, whereas the other miRNAs were differentially expressed only in active CD. ${ }^{59}$

In UC patients, five miRNAs (miR-28-5p, miR-151-5p, miR-199a-5p, miR-340*, miRplusE1271) were increased and no miRNAs were significantly decreased in the serum of patients with active UC but not inactive UC compared to healthy controls. miR-103-2*, miR-362-3p, and miR-532-3p were increased, and miR-505* was decreased in the blood of both inactive and active UC patients. .59

In that study, eight miRNAs (miR-28-5p, miR-103-2*, miR-149*, miR-151-5p, miR-340*, miR-505*, miR-532-3p, miRplus-E1153) could distinguish active CD from active UC by real-time PCR. Of these, seven were significantly increased in active UC as compared to active $\mathrm{CD}$, while only miR-505* was significantly decreased in active UC. ${ }^{59}$ When the impact of location was examined, miRNA expression between the Crohn's ileitis and Crohn's colitis groups did not significantly differ. Furthermore, there were no differences in peripheral miRNA expression between UC patients with extensive and distal colitis. The influence of severity of inflammation on miRNA expression was not examined in this study.

\section{SNPS IN PRE-MIRNAS CODING REGIONS IN IBD}

The impact of single nucleotide polymorphisms (SNPs) in pre-miRNA coding regions conveying a susceptibility to IBD and clinical activity has also recently been examined. A study of 170 UC patients and 403 healthy controls in a Japanese cohort investigated the association of three SNPs (rs11614913, rs2910164, and rs3746444) in pre-miRNA coding regions (miR-196a2, miR-146a, and miR-499) ${ }^{60}$ The authors evaluated these SNPs because of their association with other disease states, in particular multiple cancers. ${ }^{61-64}$ In this study, the AG genotype of rs3746444 in miR-499 was significantly associated with susceptibility to UC, disease onset at an older age, left-sided colitis, pancolitis, higher number of times hospitalized, steroid dependence, and refractory phenotype. In contrast, the rs3746444 AA genotype was inversely associated with the number of times hospitalized, steroid dependence, and refractoriness to medical therapy. In addition, the rs1161913 TT genotype held a significantly higher risk of being refractory to medical treatment. ${ }^{60}$ Although there were several outcome measurements that reached statistical significance, this study was likely not powered adequately to detect differences in subgroup analysis, so larger trials are needed to confirm these findings. 


\section{MIRNAS IN INFLAMMATION-ASSOCIATED CANCER}

Several previous studies have demonstrated differential expression of miRNAs in several malignancies, including colon cancer. ${ }^{65-68}$ Aberrant expression of miRNAs in malignant cells can lead to inhibition of tumor suppressors or upregulation of proto-oncogenes. Examples include the tumor suppressor gene, p53, and proto-oncogenes ras and myc. ${ }^{69-71}$ Abnormal translation of these genes has been implicated in colorectal carcinogenesis. ${ }^{72}$ Furthermore, two growth factors, vascular endothelial growth factor receptor (VEGF) and epidermal growth factor receptor (EGFR), which play important roles in the pathogenesis of colorectal carcinoma (CRC), were established as miRNA targets. ${ }^{73,74}$

Patients with long-standing IBD-associated colitis are at increased risk for the development of colon cancer. ${ }^{75}$ While the exact mechanisms of IBD-associated carcinogenesis remain obscure, cancer is believed to develop secondary to repeated tissue injury and prolonged inflammation. Given the differential expression of miRNAs in tissue inflammation and various cancers, it is logical that miRNAs play an important role in the IBD-associated cancer development.

miRNA profiles in IBD-associated neoplasia were examined in a study by Olaru et al 76 where miRNA microarrays were performed on tissue from eight patients with inflamed nondysplastic IBD and eight patients with IBD-associated dysplasia. In this analysis, 22 miRNAs were significantly upregulated and 10 miRNAs downregulated in dysplasia compared to inflamed tissue. ${ }^{76}$ The authors examined miR-31 in a larger cohort of patients and found expression to increase linearly from normal tissue to unaffected colon tissue from IBD patients to inflamed colon tissue to IBD-associated neoplasia. ${ }^{76}$ In comparing IBDassociated neoplasia to normal tissue, miR-31 had an area under the ROC curve of $0.997 .{ }^{76}$ For the comparison of IBD-associated neoplasia to inflamed, nondysplastic tissue, the area under the ROC curve for miR-31 was $0.877 .{ }^{76}$ Hypoxia inducible factor-1 (FIH-1) was found to be a target in silico for miR-31 and confirmed in vitro in colon cancer cells. ${ }^{76}$

\section{CONCLUSION}

Regulation of gene expression by miRNAs plays a significant role in the innate and adaptive immune system, and changes in miRNA expression are described in many immunemediated diseases. Likewise, miRNA expression profiles are dysregulated at the tissue level in active UC, Crohn's ileitis, Crohn's colitis, and IBD-associated dysplasia. miRNA expression profiles also differ in the peripheral blood of $\mathrm{UC}$ and $\mathrm{CD}$ patients. These differences in miRNA expression may lead to diagnostic biomarkers and add to our understanding of IBD pathogenesis; however, the majority of studies to date that have examined miRNA expression in IBD have been small, without uniformity between study populations or tissue collection methods. As such, larger studies to examine the clinical utility of these profiles are needed.

The detection and study of miRNAs in IBD is in its infancy, although has the potential to advance clinical management of IBD as well as add to our knowledge of IBD pathogenesis. The detection of miRNAs in peripheral blood and tissues may become a method for the 
diagnosis of IBD as well as distinguishing disease phenotypes and activity. Further studies that elucidate of the role of miRNAs in IBD may also delineate mechanisms of disease activity and further our understanding of the biology of IBD, potentially leading to new therapeutic targets.

\section{References}

1. Lawrance IC, Fiocchi C, Chakravarti S. Ulcerative colitis and Crohn's disease: distinctive gene expression profiles and novel susceptibility candidate genes. Hum Mol Genet. 2001; 10:445-456. [PubMed: 11181568]

2. Noble CL, Abbas AR, Cornelius J, et al. Regional variation in gene expression in the healthy colon is dysregulated in ulcerative colitis. Gut. 2008; 57:1398-1405. [PubMed: 18523026]

3. Okahara S, Arimura Y, Yabana T, et al. Inflammatory gene signature in ulcerative colitis with cDNA macroarray analysis. Aliment Pharmacol Ther. 2005; 21:1091-1097. [PubMed: 15854170]

4. Wu F, Dassopoulos T, Cope L, et al. Genome-wide gene expression differences in Crohn's disease and ulcerative colitis from endoscopic pinch biopsies: insights into distinctive pathogenesis. Inflamm Bowel Dis. 2007; 13:807-821. [PubMed: 17262812]

5. Mesko B, Poliska S, Szegedi A, et al. Peripheral blood gene expression patterns discriminate among chronic inflammatory diseases and healthy controls and identify novel targets. BMC Med Genomics. 2010; 3:15. [PubMed: 20444268]

6. Fujino S, Andoh A, Bamba S, et al. Increased expression of interleukin 17 in inflammatory bowel disease. Gut. 2003; 52:65-70. [PubMed: 12477762]

7. Fuss IJ, Heller F, Boirivant M, et al. Nonclassical CD1d-restricted NK T cells that produce IL-13 characterize an atypical Th2 response in ulcerative colitis. J Clin Invest. 2004; 113:1490-1497. [PubMed: 15146247]

8. Abraham C, Cho JH. Inflammatory bowel disease. N Engl J Med. 2009; 361:2066-2078. [PubMed: 19923578]

9. Rybaczyk L, Rozmiarek A, Circle K, et al. New bioinformatics approach to analyze gene expressions and signaling pathways reveals unique purine gene dysregulation profiles that distinguish between CD and UC. Inflamm Bowel Dis. 2009; 15:971-984. [PubMed: 19253308]

10. Arijs I, Li K, Toedter G, et al. Mucosal gene signatures to predict response to infliximab in patients with ulcerative colitis. Gut. 2009; 58:1612-1619. [PubMed: 19700435]

11. Bartel DP. MicroRNAs: genomics, biogenesis, mechanism, and function. Cell. 2004; 116:281-297. [PubMed: 14744438]

12. Lewis BP, Burge CB, Bartel DP. Conserved seed pairing, often flanked by adenosines, indicates that thousands of human genes are microRNA targets. Cell. 2005; 120:15-20. [PubMed: 15652477]

13. Lewis BP, Shih IH, Jones-Rhoades MW, et al. Prediction of mammalian microRNA targets. Cell. 2003; 115:787-798. [PubMed: 14697198]

14. Friedman RC, Farh KK, Burge CB, et al. Most mammalian mRNAs are conserved targets of microRNAs. Genome Res. 2009; 19:92-105. [PubMed: 18955434]

15. Liu W, Mao SY, Zhu WY. Impact of tiny miRNAs on cancers. World J Gastroenterol. 2007; 13:497-502. [PubMed: 17278213]

16. Ambros V. The functions of animal microRNAs. Nature. 2004; 431:350-355. [PubMed: 15372042]

17. McKenna LB, Schug J, Vourekas A, et al. MicroRNAs control intestinal epithelial differentiation, architecture, and barrier function. Gastroenterology. 2010; 139:1654-1664. 1664 e1651. [PubMed: 20659473]

18. He L, Thomson JM, Hemann MT, et al. A microRNA polycistron as a potential human oncogene. Nature. 2005; 435:828-833. [PubMed: 15944707]

19. Lee RC, Feinbaum RL, Ambros V. The C. elegans heterochronic gene lin-4 encodes small RNAs with antisense complementarity to lin-14. Cell. 1993; 75:843-854. [PubMed: 8252621] 
20. Griffiths-Jones S, Grocock RJ, van Dongen S, et al. miRBase: microRNA sequences, targets and gene nomenclature. Nucleic Acids Res. 2006; 34:D140-144. [PubMed: 16381832]

21. Lee Y, Ahn C, Han J, et al. The nuclear RNase III Drosha initiates microRNA processing. Nature. 2003; 425:415-419. [PubMed: 14508493]

22. Yi R, Qin Y, Macara IG, et al. Exportin-5 mediates the nuclear export of pre-microRNAs and short hairpin RNAs. Genes Dev. 2003; 17:3011-3016. [PubMed: 14681208]

23. Lund E, Guttinger S, Calado A, et al. Nuclear export of microRNA precursors. Science. 2004; 303:95-98. [PubMed: 14631048]

24. Robb GB, Rana TM. RNA helicase A interacts with RISC in human cells and functions in RISC loading. Mol Cell. 2007; 26:523-537. [PubMed: 17531811]

25. Kong YW, Cannell IG, de Moor CH, et al. The mechanism of micro-RNA-mediated translation repression is determined by the promoter of the target gene. Proc Natl Acad Sci U S A. 2008; 105:8866-8871. [PubMed: 18579786]

26. Lu LF, Liston A. MicroRNA in the immune system, microRNA as an immune system. Immunology. 2009; 127:291-298. [PubMed: 19538248]

27. Dunne A, O'Neill LA. Adaptor usage and Toll-like receptor signaling specificity. FEBS Lett. 2005; 579:3330-3335. [PubMed: 15876435]

28. Kracht M, Saklatvala J. Transcriptional and post-transcriptional control of gene expression in inflammation. Cytokine. 2002; 20:91-106. [PubMed: 12453467]

29. Taganov KD, Boldin MP, Chang KJ, et al. NF-kappaB-dependent induction of microRNA miR-146, an inhibitor targeted to signaling proteins of innate immune responses. Proc Natl Acad Sci U S A. 2006; 103:12481-12486. [PubMed: 16885212]

30. Bazzoni F, Rossato M, Fabbri M, et al. Induction and regulatory function of miR-9 in human monocytes and neutrophils exposed to proinflammatory signals. Proc Natl Acad Sci U S A. 2009; 106:5282-5287. [PubMed: 19289835]

31. Selbach M, Schwanhausser B, Thierfelder N, et al. Widespread changes in protein synthesis induced by microRNAs. Nature. 2008; 455:58-63. [PubMed: 18668040]

32. Korb M, Rust AG, Thorsson V, et al. The Innate Immune Database (IIDB). BMC Immunol. 2008; 9:7. [PubMed: 18321385]

33. Gantier MP. New perspectives in MicroRNA regulation of innate immunity. J Interferon Cytokine Res. 2010; 30:283-289. [PubMed: 20477549]

34. O'Connell RM, Taganov KD, Boldin MP, et al. MicroRNA-155 is induced during the macrophage inflammatory response. Proc Natl Acad Sci U S A. 2007; 104:1604-1609. [PubMed: 17242365]

35. Tili E, Michaille JJ, Cimino A, et al. Modulation of miR-155 and miR-125b levels following lipopolysaccharide/TNF-alpha stimulation and their possible roles in regulating the response to endotoxin shock. J Immunol. 2007; 179:5082-5089. [PubMed: 17911593]

36. Ceppi M, Pereira PM, Dunand-Sauthier I, et al. MicroRNA-155 modulates the interleukin-1 signaling pathway in activated human monocyte-derived dendritic cells. Proc Natl Acad Sci U S A. 2009; 106:2735-2740. [PubMed: 19193853]

37. Lu LF, Thai TH, Calado DP, et al. Foxp3-dependent microRNA155 confers competitive fitness to regulatory T cells by targeting SOCS1 protein. Immunity. 2009; 30:80-91. [PubMed: 19144316]

38. Rodriguez A, Vigorito E, Clare S, et al. Requirement of bic/microRNA-155 for normal immune function. Science. 2007; 316:608-611. [PubMed: 17463290]

39. Zhou X, Jeker LT, Fife BT, et al. Selective miRNA disruption in T reg cells leads to uncontrolled autoimmunity. J Exp Med. 2008; 205:1983-1991. [PubMed: 18725525]

40. Chen CZ, Li L, Lodish HF, et al. MicroRNAs modulate hematopoietic lineage differentiation. Science. 2004; 303:83-86. [PubMed: 14657504]

41. Eis PS, Tam W, Sun L, et al. Accumulation of miR-155 and BIC RNA in human B cell lymphomas. Proc Natl Acad Sci U S A. 2005; 102:3627-3632. [PubMed: 15738415]

42. Thai TH, Calado DP, Casola S, et al. Regulation of the germinal center response by microRNA-155. Science. 2007; 316:604-608. [PubMed: 17463289] 
43. Zhou B, Wang S, Mayr C, et al. miR-150, a microRNA expressed in mature B and T cells, blocks early B cell development when expressed prematurely. Proc Natl Acad Sci U S A. 2007; 104:7080-7085. [PubMed: 17438277]

44. Alevizos I, Illei GG. MicroRNAs as biomarkers in rheumatic diseases. Nat Rev Rheumatol. 2010; 6:391-398. [PubMed: 20517293]

45. Nakasa T, Miyaki S, Okubo A, et al. Expression of microRNA-146 in rheumatoid arthritis synovial tissue. Arthritis Rheum. 2008; 58:1284-1292. [PubMed: 18438844]

46. Stanczyk J, Pedrioli DM, Brentano F, et al. Altered expression of MicroRNA in synovial fibroblasts and synovial tissue in rheumatoid arthritis. Arthritis Rheum. 2008; 58:1001-1009. [PubMed: 18383392]

47. Stanczyk J, Ospelt C, Karouzakis E, et al. Altered expression of miR-203 in rheumatoid arthritis synovial fibroblasts and its role in fibroblast activation. Arthritis Rheum. 2011; 63:373-381. [PubMed: 21279994]

48. Pauley KM, Satoh M, Chan AL, et al. Upregulated miR-146a expression in peripheral blood mononuclear cells from rheumatoid arthritis patients. Arthritis Res Ther. 2008; 10:R101. [PubMed: 18759964]

49. Dai Y, Huang YS, Tang M, et al. Microarray analysis of microRNA expression in peripheral blood cells of systemic lupus erythematosus patients. Lupus. 2007; 16:939-946. [PubMed: 18042587]

50. Tang Y, Luo X, Cui H, et al. MicroRNA-146A contributes to abnormal activation of the type I interferon pathway in human lupus by targeting the key signaling proteins. Arthritis Rheum. 2009; 60:1065-1075. [PubMed: 19333922]

51. Zhang J, Yang B, Ying B, et al. Association of pre-microRNAs genetic variants with susceptibility in systemic lupus erythematosus. Mol Biol Rep. 2011; 38:1463-1468. [PubMed: 20845080]

52. Te JL, Dozmorov IM, Guthridge JM, et al. Identification of unique microRNA signature associated with lupus nephritis. PLoS One. 2010; 5:e10344. [PubMed: 20485490]

53. Sonkoly E, Wei T, Janson PC, et al. MicroRNAs: novel regulators involved in the pathogenesis of psoriasis? PLoS One. 2007; 2:e610. [PubMed: 17622355]

54. Sano S, Chan KS, Carbajal S, et al. Stat3 links activated keratinocytes and immunocytes required for development of psoriasis in a novel transgenic mouse model. Nat Med. 2005; 11:43-49. [PubMed: 15592573]

55. Wu F, Zikusoka M, Trindade A, et al. MicroRNAs are differentially expressed in ulcerative colitis and alter expression of macrophage inflammatory peptide-2 alpha. Gastroenterology. 2008; 135:1624-1635. e1624. [PubMed: 18835392]

56. Takagi T, Naito Y, Mizushima K, et al. Increased expression of microRNA in the inflamed colonic mucosa of patients with active ulcerative colitis. J Gastroenterol Hepatol. 2010; 25(suppl 1):S129_ 133. [PubMed: 20586854]

57. Fasseu M, Treton X, Guichard C, et al. Identification of restricted subsets of mature microRNA abnormally expressed in inactive colonic mucosa of patients with inflammatory bowel disease. PLoS One. 2010; 5:e13160. [PubMed: 20957151]

58. Wu F, Zhang S, Dassopoulos T, et al. Identification of microRNAs associated with ileal and colonic Crohn's disease. Inflamm Bowel Dis. 2010; 16:1729-1738. [PubMed: 20848482]

59. Wu F, Guo NJ, Tian H, et al. Peripheral blood microRNAs distinguish active ulcerative colitis and Crohn's disease. Inflamm Bowel Dis. 2011; 17:241-250. [PubMed: 20812331]

60. Okubo M, Tahara T, Shibata T, et al. Association study of common genetic variants in premicroRNAs in patients with ulcerative colitis. J Clin Immunol. 2010 Epub ahead of print.

61. Hu Z, Chen J, Tian T, et al. Genetic variants of miRNA sequences and non-small cell lung cancer survival. J Clin Invest. 2008; 118:2600-2608. [PubMed: 18521189]

62. Tian T, Shu Y, Chen J, et al. A functional genetic variant in microRNA-196a2 is associated with increased susceptibility of lung cancer in Chinese. Cancer Epidemiol Biomarkers Prev. 2009; 18:1183-1187. [PubMed: 19293314]

63. Jazdzewski K, Murray EL, Franssila K, et al. Common SNP in pre-miR-146a decreases mature miR expression and predisposes to papillary thyroid carcinoma. Proc Natl Acad Sci U S A. 2008; 105:7269-7274. [PubMed: 18474871] 
64. Xu T, Zhu Y, Wei QK, et al. A functional polymorphism in the miR-146a gene is associated with the risk for hepatocellular carcinoma. Carcinogenesis. 2008; 29:2126-2131. [PubMed: 18711148]

65. Lu J, Getz G, Miska EA, et al. MicroRNA expression profiles classify human cancers. Nature. 2005; 435:834-838. [PubMed: 15944708]

66. Michael MZ, SMOC, van Holst Pellekaan NG, et al. Reduced accumulation of specific microRNAs in colorectal neoplasia. Mol Cancer Res. 2003; 1:882-891. [PubMed: 14573789]

67. Schetter AJ, Leung SY, Sohn JJ, et al. MicroRNA expression profiles associated with prognosis and therapeutic outcome in colon adenocarcinoma. JAMA. 2008; 299:425-436. [PubMed: 18230780]

68. Schepeler T, Reinert JT, Ostenfeld MS, et al. Diagnostic and prognostic microRNAs in stage II colon cancer. Cancer Res. 2008; 68:6416-6424. [PubMed: 18676867]

69. Xi Y, Shalgi R, Fodstad O, et al. Differentially regulated micro-RNAs and actively translated messenger RNA transcripts by tumor suppressor p53 in colon cancer. Clin Cancer Res. 2006; 12:2014-2024. [PubMed: 16609010]

70. Johnson SM, Grosshans H, Shingara J, et al. RAS is regulated by the let-7 microRNA family. Cell. 2005; 120:635-647. [PubMed: 15766527]

71. O’Donnell KA, Wentzel EA, Zeller KI, et al. c-Myc-regulated microRNAs modulate E2F1 expression. Nature. 2005; 435:839-843. [PubMed: 15944709]

72. Untawale S, Blick M. Oncogene expression in adenocarcinomas of the colon and in colon tumorderived cell lines. Anticancer Res. 1988; 8:1-7. [PubMed: 3282475]

73. Li X, Carthew RW. A microRNA mediates EGF receptor signaling and promotes photoreceptor differentiation in the Drosophila eye. Cell. 2005; 123:1267-1277. [PubMed: 16377567]

74. Hua Z, Lv Q, Ye W, et al. MiRNA-directed regulation of VEGF and other angiogenic factors under hypoxia. PLoS One. 2006; 1:e116. [PubMed: 17205120]

75. Ekbom A, Helmick C, Zack M, et al. Ulcerative colitis and colorectal cancer. A population-based study. N Engl J Med. 1990; 323:1228-1233. [PubMed: 2215606]

76. Olaru AV, Selaru FM, Mori Y, et al. Dynamic changes in the expression of MicroRNA-31 during inflammatory bowel disease-associated neoplastic transformation. Inflamm Bowel Dis. 2011; 17:221-231. [PubMed: 20848542] 


\section{Table 1}

Summary of studies examining miRNAs in IBD.

\begin{tabular}{|c|c|c|c|c|}
\hline Reference & Comparison & Source & Increased Expression & Decreased Expression \\
\hline Wu et al (55) & $\begin{array}{l}\text { Active UC vs. } \\
\text { Healthy Controls }\end{array}$ & Sigmoid Colon & $\begin{array}{l}\text { miR-16, miR-21, miR-23a, miR-24, } \\
\text { miR-29a, miR-126, miR-195, Let-7f }\end{array}$ & miR-192, miR-375, miR-422b \\
\hline $\begin{array}{l}\text { Takagi et al } \\
(56)\end{array}$ & $\begin{array}{l}\text { Active UC vs. } \\
\text { Healthy Controls }\end{array}$ & Colon & miR-21, miR-155 & \\
\hline Wu et al (58) & $\begin{array}{l}\text { Active CD vs. } \\
\text { Healthy Controls }\end{array}$ & $\begin{array}{l}\text { Sigmoid Colon } \\
\text { Terminal Ileum }\end{array}$ & $\begin{array}{l}\text { miR-23b, miR-106a, miR-191 } \\
\text { miR-16, miR-21, miR-223, miR-594 }\end{array}$ & miR-19b, miR-629 \\
\hline $\begin{array}{l}\text { Fasseu et al } \\
(57)\end{array}$ & $\begin{array}{l}\text { Active UC vs. } \\
\text { Healthy Controls } \\
\text { Inactive UC vs. } \\
\text { Healthy Controls } \\
\text { Active CD vs. } \\
\text { Healthy Controls } \\
\text { Inactive CD vs. } \\
\text { Healthy Controls } \\
\text { Inactive UC vs. } \\
\text { Inactive CD }\end{array}$ & Colon & $\begin{array}{l}\text { miR-7, miR-31, miR-135b, miR-223, } \\
\text { miR-29a, miR-29b, miR-126*, } \\
\text { miR-127-3p, miR324-3p } \\
\text { miR-196a, miR-29a, miR-29b, } \\
\text { miR-126*, miR-127-3p, miR324-3p } \\
\text { miR-9, miR-126, miR-130a, miR-181c, } \\
\text { miR-375, miR-26a, miR-29b, miR-30b, } \\
\text { miR-34c-5p, miR-126*, miR127-3p, } \\
\text { miR-133b, miR-155, miR-196a, } \\
\text { miR324-3p, miR-21, miR-22, miR-29c, } \\
\text { miR-31, miR-106a, miR-146a, } \\
\text { miR146b-3p, miR-150 } \\
\text { miR-9*, miR-30a*, miR-30c, miR-223 } \\
\text { miR-25a, miR-29b, miR-30b, } \\
\text { miR-34c-5p, miR-126*, miR127-3p, } \\
\text { miR-133b, miR-155, miR-196a, } \\
\text { miR324-3p, miR-21, miR-22, miR-29c, } \\
\text { miR-31, miR-106a, miR-146a, } \\
\text { miR146b-3p, miR-150 }\end{array}$ & $\begin{array}{l}\text { miR-188-5p, miR-25, miR-320a, } \\
\text { miR-346 } \\
\text { miR-188-5p, miR-25, miR-320a, } \\
\text { miR-346 } \\
\text { miR-150, miR-196b, } \\
\text { miR-199a-3p, miR-199b-5p, } \\
\text { miR-223, miR-320a }\end{array}$ \\
\hline Wu et al (59) & $\begin{array}{l}\text { Active UC vs. } \\
\text { Healthy Controls } \\
\text { Active CD vs. } \\
\text { Healthy Controls } \\
\text { Active UC vs. Active } \\
\text { CD }\end{array}$ & Peripheral blood & $\begin{array}{l}\text { miR-28-5p, miR-151-5p, miR-199a-5p, } \\
\text { miR-340*, miRplus-E1271, } \\
\text { miR-103-2*, miR-362-3p, miR-532-3p } \\
\text { miR-199p-5a, miR-362-3p, miR-340*, } \\
\text { miR-532-3p, miRplus- E1271 } \\
\text { miR-28-5p, miR-103-2*, miR-149*, } \\
\text { miR-151-5p, miR-340*, miR-532-3p, } \\
\text { miRplus-E1153 }\end{array}$ & $\begin{array}{l}\text { miR-505* } \\
\text { miR-149*, miRplus-F1065 } \\
\text { miR-505* }\end{array}$ \\
\hline $\begin{array}{l}\text { Olaru et al } \\
(76)\end{array}$ & $\begin{array}{l}\text { IBD-associated } \\
\text { dysplasia vs. active } \\
\text { IBD }\end{array}$ & Rectum & $\begin{array}{l}\text { miR-552, miR-31, miR-31*, miR-203, } \\
\text { miR-215, miR-135b, miR-200b*, } \\
\text { miR-200a, miR-200c, miR-194, } \\
\text { miR-200b, miR-192, miR-192*, } \\
\text { miR-141, miR-96, miR-194*, } \\
\text { miR-200a*, miR-429, miR-375, } \\
\text { miR-424*, miR-183, miR-224, }\end{array}$ & $\begin{array}{l}\text { miR- } 892 b, \text { miR-122, miR-223, } \\
\text { miR-501-5p, miR-146b-5p, } \\
\text { miR-142-3p, miR-139-5p, } \\
\text { miR-155, miR-1288, miR-490-3p }\end{array}$ \\
\hline
\end{tabular}

